\title{
Epibulbar lipodermoid-preauricular appendage-polythelia syndrome
}

INSERM

\section{Source}

INSERM. (1999). Orphanet: an online rare disease and orphan drug data base. Epibulbar lipodermoid-preauricular appendage-polythelia syndrome. ORPHA:231742

Epibulbar lipodermoid preauricular appendages polythelia is a branchial arch syndrome described in seven sibs of one Danish family and characterized by supernumerary nipples (polythelia), preauricular appendages and often binocular epibulbar lipodermoids or unilateral subconjunctival lipodermoids. 